14

\title{
Поли-2(1-циклопент-2-ен-1-ил)анилин: синтез и исследование электрофизических и физико-химических свойств
}

\author{
(С) Ю.Н. Биглова ${ }^{1,2}$, Р.Б. Салихов ${ }^{2, \uparrow}$, И.Н. Сафраргалин ${ }^{2}$, Т.Р. Салихов ${ }^{2}$, А.Г. Мустафин ${ }^{1,2}$ \\ ${ }^{1}$ Уфримский институт химии УФИЦ РАН, \\ Уфра, Россия \\ ${ }^{2}$ Башкирский государственный университет, \\ Уфра, Россия \\ IE-mail: salikhovrb@yandex.ru
}

Поступила в Редакцию 26 марта 2019 г.

В окончательной редакции 11 июня 2019 г.

Принята к публикации 18 июня 2019 г.

Осуществлен синтез нового электронодонорного проводящего полимера - 2-(1-циклопент-2-ен-1-ил)анилина и проведена оптимизация полимеризационного процесса по мольному соотношению мономер: окислитель и времени реакции. Оценены извлечение и растворимость функционализированного полианилина в отличающихся по полярности типовых органических растворителях. Для полученного высокомолекулярного соединения изучена зависимость электропроводности от температуры, рассчитаны подвижности носителей заряда, проведен термогравиметрический анализ.

Ключевые слова: полианалин, тонкие пленки, электропроводность, морфология, термогравиметрия.

DOI: 10.21883/FTT.2019.11.48437.432

\section{1. Ведение}

Полианилин (ПАНИ) - один из наиболее ярких представителей класса электропроводящих полимеров. Исследование ПАНИ и других органических высокомолекулярных соединений показало, что они обладают свойствами полупроводников. Полимеры способны находиться в разных состояниях окисления и подобно неорганическим полупроводникам дают закономерный отклик на внешнее воздействие: меняют свою электропроводность, цвет, плотность, магнитные свойства, гидрофильностьгидрофобность. Следует отметить, что ПАНИ обладает контролируемой электронной проводимостью в диапазоне $10^{-10}-10^{1} \mathrm{~S} / \mathrm{cm}$ в сочетании с ионной проводимостью, окислительно-восстановительной активностью, нелинейными оптическими свойствами и парамагнетизмом. В дополнение к этому, интенсификация изучения и практического использования полимера обусловлена рядом преимуществ: доступность и невысокая стоимость сырья, отсутствие в необходимости высокотехнологичного оборудования при получении, простота процессов допирования и дедопирования и экологическая безопасность [1]. Именно из-за наличия уникального комплекса свойств ПАНИ первым среди электропроводящих полимеров стал использоваться на практике. Например, в энергосберегающих устройствах — литиевых аккумуляторах, занимающих большую долю рынка источников питания мобильных телефонов, ноутбуков и при разработке устройств альтернативной энергетики - топливных элементов [2-4]. Недавно обнаруженная биосовместимость нетоксичного ПАНИ обусловила перспектив- ность биомедицинского направления исследований этого полимера [5-7].

В связи с расширяющимся применением в промышленности агрессивных сред обостряется проблема сохранения металлофонда (потери от коррозии стальных объектов достигают 20\% годового производства), использование ПАНИ в качестве ингибитора коррозии не менее перспективно. Преимуществом данного ингибитора является способность анодно пассивировать металл и сдерживать коррозионные процессы под пленочным покрытием и в области его дефектов [8]. Диапазон потенциально возможного применения ПАНИ очень широк, однако существуют проблемы, сдерживающие его практическое использование. Прежде всего сюда следует отнести синтез образцов ПАНИ с воспроизводимыми свойствами: одни из них демонстрируют электропроводность десятки и даже сотни $\mathrm{S} / \mathrm{cm}$, тогда как удельная электропроводность других не превышает $10^{-10} \mathrm{~S} / \mathrm{cm}$; отличаются они и спектральными, магнитными характеристиками и могут иметь принципиально разную морфологию. Неопределенность такого рода приводит к множеству неоднозначных, а часто противоречивых результатов и требует глубокого изучения процесса окислительной полимеризации мономера - анилина.

Следующая проблема связана с созданием материалов для практического применения. На практике ПАНИ, употребляющийся в составе композитов, отличается плохими механическими свойствами: крайне низкой адгезией к другим материалам. Поэтому второй компонент не только дополняет свойства электропроводящего полимера, но и выполняет функции носителя. В то же время получение композитов ПАНИ традиционны- 


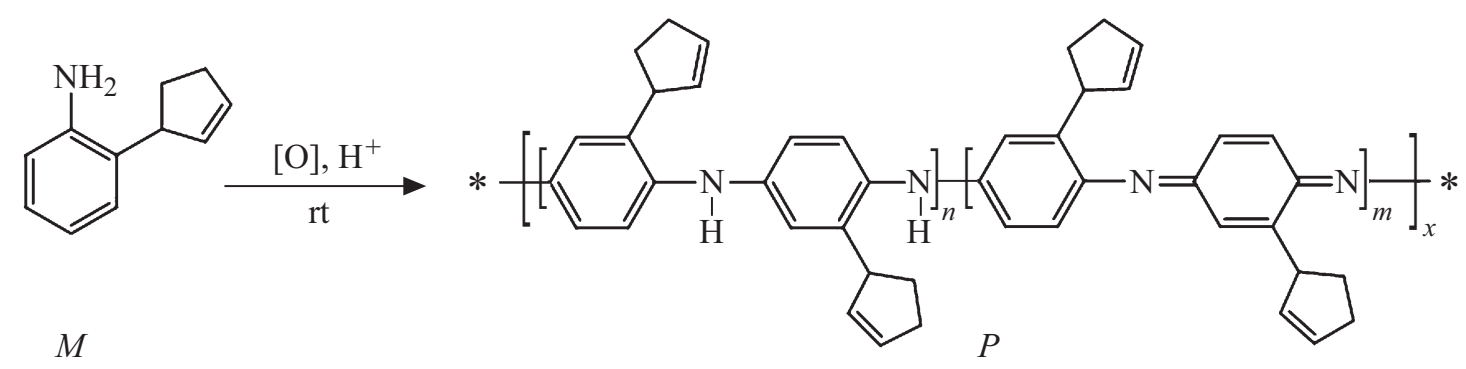

Рис. 1. Схема окисления 2-(1-циклопент-2-ен-1-ил)анилина $(M)$.

ми методами проблематично. Механические смеси не обнаруживают хорошее качество, а методы совмещения из расплава и из раствора в большинстве случае неприемлемы, поскольку ПАНИ относится к категории не перерабатываемых материалов (полимер не плавится и практически нерастворим в типовых органических растворителях) [9-11]. Основополагающим моментом не только получения ПАНИ, но и композиционных материалов на его основе, является синтез. Несмотря на кажущуюся простоту, окислительная полимеризация анилина - сложная многостадийная реакция, включающая два взаимосвязанных процесса: сборку мономерных звеньев и самоорганизацию растущих цепей в надмолекулярные структуры. В электропроводящем ПАНИ полимерные цепи на 95-98\% состоят из паразамещенныхмономерных звеньев, связанных по типу „голова-хвост“, что обеспечивает развитую систему полисопряжения. По завершении синтеза сформировавшиеся агломераты макромолекул уже невозможно ни расплавить, ни растворить. Следовательно, синтез необратимо фиксирует не только молекулярную сборку цепей, но и их надмолекулярную упаковку. Для исключения перечисленных недостатков ПАНИ прибегают к его модификации. Как альтернативный вариант оптимизации эксплуатационных характеристик полимера представляется функционализация исходного мономера. Например, введение в полимеризационный процесс замещенных анилинов - орто-анизидина, орто-толуидина, что приводит к образованию способных растворяться в органических растворителях продуктов. При осуществлении электрохимической полимеризации орто-толуидина в работе [12] показано влияние используемой в качестве электролита кислоты (серная, сульфаминовая и сульфосалициловая) на электропроводность целевого продукта. Авторы отмечают, что хотя синтезированный с участием серной кислоты полимер и обладает высокой электропроводностью, но рН-диапазон у него узок. Предлагается способ получения демонстрирующих хорошую электропроводность и растворимость сополимеров на базе орто-анизидина и орто-толуидина (электрохимическая полимеризация) [13]. При этом полимеры отличаются упорядоченной структурой, а отлитые пленки сохраняют стабильность свойств при повышенной температуре в средах с высоким значением рН. Обращается внимание авторами публикации и на тот факт, что путем варьирования соотношения сомономеров достигается ощутимое изменение физических и физико-химических свойств электропроводящих высокомолекулярных соединений.

В связи с изложенным выше, цель данной работы оптимизация процесса преобразования мономера 2-(1-циклопент-2-ен-1-ил)анилина в новое высокомолекулярное соединение и изучение его электрофизических и физико-химических свойств.

\section{2. Экспериментальная часть}

\section{1. Материалы}

Используемые в работе коммерчески доступные реагенты и растворители, такие как персульфат аммония, поливинилпиролидон, получали из фирмы Aldrich и использовали без дальнейшей очистки. Органические растворители, такие как толуол, хлороформ, ацетонитрил, диметилформамид (ДМФА), этанол, хлорбензол после очистки общепринятыми методами имели характеристики, соответствующие литературным данным [4,15].

Мономер 2-(1-циклопент-2-ен-1-ил)анилин $\quad(M)$ (рис. 1) синтезирован нами по методике, представленной в [16], дистиллировали под вакуумом для удаления окисленных примесей и характеризовали с привлечением спектральных методов анализа, которые совпадают с описанными в литературе.

\section{2. Синтез полимера}

Поли-2-(1-циклопент-2-ен-1-ил)анилин $(P)$ получали методом окислительной полимеризации путем смешивания при $0^{\circ} \mathrm{C}$ равных объемов растворов $M(0.2 \mathrm{~mol})$ в соляной кислоте $(0.2 \mathrm{M})$ и персульфата аммония $(0.25 \mathrm{~mol})$ в соляной кислоте $(0.2 \mathrm{M})$ (рис. 1$)$. В течение суток в реакционной колбе протекала экзотермическая реакция, сопровождавшаяся изменением окраски реагирующей массы и выпадением обильного чернокоричневого осадка протонированной эмеральдиновой формы $P$. Побочные продукты синтеза, сульфат аммония и соляная кислота, а также небольшие количества олигомеров модифицированного анилина удаляли многократным промыванием осадка в дистиллированной 
воде. Полученный фильтрат высушивали в вакууме при комнатной температуре.

Структура синтезированного функционализированного полианилина $P$ доказана комплексом физико-химических методов анализа - ЯМР ${ }^{1} \mathrm{H},{ }^{13} \mathrm{C}$, ИК, УФ-спектроскопия.

ИК спектр, $v$ cm $^{-1}:$ 669, 772, 972, 1046, 1165, 1259, $1310,1492,1603,1655,2361,2726,3350$. УФ спектр, $\lambda$, nm: 210, 590,676 nm.

Спектр ЯМР ${ }^{1} \mathrm{H} \quad\left(\mathrm{CDCl}_{3}\right), \delta, \quad$ м.д.: $1.71-2.54$ (м, $\mathrm{CH}_{2}-\mathrm{CH}_{2}$ ), 2.98-3.04 (M, 1H, $\left.\mathrm{C}_{5} \mathrm{H}_{7}\right), 4.02$ (c, $1 \mathrm{H}, \mathrm{NH}$ ), 6.26-6.73 ( $, 2 \mathrm{H}, \mathrm{CH}=\mathrm{CH}), 6.58-7.28\left(\mathrm{M}, 3 \mathrm{H}, \mathrm{C}_{6} \mathrm{H}_{5}\right)$. Спектр ЯМР ${ }^{13} \mathrm{C}\left(\mathrm{CDCl}_{3}\right), \delta$, м.д.: 30.56, 32.11, 33.58, $34.13,36.88,43.48,45.43,52.45,53.13,110.90,111.34$, $112.06,116.87,118.33,121.30,123.83,127.32,128.06$, $131.33,136.86,139.07,143.93,144.10,146.03,147.81$, 155.91, 169.13 .

\section{3. Методики исследования}

Растворимость полимера $M$ в выбранных растворителях определяли путем уравновешивания избыточного количества твердого вещества с растворителем методом встряхивания в колбе Хигучи и Коннорса [17]. Bсе анализы осуществляли при атмосферном давлении и комнатной температуре.

Изготовление образцов для электрофизических исследований выполняли по следующему алгоритму. Первоначально осуществляли напыление электродов. Алюминиевые электроды наносились методом термического напыления в вакуумной камере на установке ВУП 5М. В качестве подложек использовали предметные стекла для микроскопических исследований с максимальной шероховатостью не более $15 \mathrm{~nm}$. При напылении оставляли зазор между электродами, равный $0.1 \mathrm{~mm}$, в который помещали исследуемые полимерные пленки. Для их получения использовали раствор полимера в хлороформе и наносили его в область зазора между электродами методомцентрифугирования. Исследование зависимости сопротивления образца от температуры (интервал $300-450 \mathrm{~K}$ ) проводили в установке, которая состоит из специальной печи с нихромовой проволокой для нагрева пленок, силового трансформатора, с помощью которого регулировали предельную температуру нагрева, цифрового мультиметра АРPA $107 \mathrm{~N}$ для измерения температуры печи и тераомметра АКИП-8602 $(2500 \mathrm{~V})$ для измерения сопротивления образцов.

Для изготовления транзисторов были использованы стеклянные пластины с омическим контактом в виде ITO. Далее на них методом центрифугирования наносился слой пленки из поливинилпиролидона, который использовался в качестве подзатворного диэлектрика. Сверху были нанесены алюминиевые электроды (исток-сток), методом термического распыления в вакуумной камере на установке ВУП 5М. В области зазора между электродами в $50 \mu \mathrm{m}$ наносили пленку исследуемого полимера методом центрифугирования.
Исследование микроструктуры наночастиц осуществляли с помощью высокоразрешающего растрового электронного микроскопа TESCAN Mira 3LMH, оснащенного детектором отраженных и обратно отраженных электронов. Съемку проводили при ускоряющем напряжении $10 \mathrm{kV}$ и вакууме порядка $10^{-3} \mathrm{~Pa}$.

Для проведения термогравиметрического анализа полимера привлекали прибор TGA/DSC-1 (фирмы „Mettler Toledo“). Навеску исследуемого образца (5-10 mg) помещали в тигель из оксида алюминия объемом $70 \mu \mathrm{L}$. Измерения проводили в динамическом режиме в интервале температур от 25 до $700^{\circ} \mathrm{C}$ при скорости нагрева $5^{\circ} \mathrm{C} / \mathrm{min}$, атмосфера-воздух. Обработку результатов осуществляли с помощью персонального компьютера. На экран компьютера выводили кривую в виде функции величины массы образца от температуры (кривая TG), а также дифференциальную кривую DTG, характеризующую тепловые эффекты, происходящие при деструкции полимера. На основе кривой TG по величине массы образца определяли: значение температуры $T_{5}$, соответствующее разложению полимера на 5\%; диапазоны разложения полимера и изменение массы $\Delta m$ на различных стадиях процесса. По максимумам на кривой, производной от кривой ТG (кривая DTG), определяли температуру $T_{m}$, при которой достигается максимальная скорость деструкции, и $m_{600}$ масса полимера после нагрева образца до температуры $600^{\circ} \mathrm{C}$ (коксовый остаток). По минимумам на кривой DTG измеряли температуру плавления полимера $T_{\text {пл}}$.

\section{3. Результаты и обсуждение}

Особенностью мономеров, участвующих в окислительной полимеризации, являются выраженные электронодонорные свойства и высокая способность к окислению. Синтезированное нами производное $P$ обладает такими свойствами благодаря наличию электронодонорного заместителя в бензольном кольце.

Как следует их литературных источников, электропроводность высокомолекулярного соединения возрастает с удлинением в нем цепи сопряжения. Имея это ввиду, мы обратились к разработке полимеризационного процесса не анилина, а его функционализированного производного и изучению физических и физико-химических свойств выделенного продукта. В качестве мономера для окислительной полимеризации был привлечен 2-(1-циклопент-2-ен-1-ил)анилин, в орто-положении ароматического ядра которого содержится увеличивающий цепь сопряжения циклоалкенильный заместитель.

\section{1. Оптимизация синтеза поли-2-(1-циклопент-2-ен-1-ил)анилина}

Ключевым моментом успешного проведения окислительной полимеризации $M$ является поддержание определенного значения $\mathrm{pH}$ реакционной среды в силу того, 
Таблица 1. Оптимизация реакции окислительной полимеризации $M$ по времени при мольном соотношении мономер: окислитель $=1.00: 1.75$

\begin{tabular}{c|c|c|c|c|c|c|c|c}
\hline $\begin{array}{c}\text { Время } \\
\text { реакции, } \mathrm{h}\end{array}$ & 3 & 6 & 12 & 18 & 24 & 36 & 48 & 60 \\
\hline Выход $P, \%$ & 1.5 & 8.0 & 23.8 & 34.0 & 39.6 & 48.3 & 45.7 & 44.8
\end{tabular}

что в щелочных, нейтральных и слабокислых средах имеет место образование олигомеров, не обладающих проводимостью. Для получения продукта необходимого качества и высокой молекулярной массы, полимеризацию $M$ проходили в среде $0.2 \mathrm{M} \mathrm{HCl}$ при использовании в качестве окислителя персульфата аммония, окислительный потенциал которого составляет $+2.01 \mathrm{~V}$. Это связано с тем, что для начала роста полимерных цепей в кислой среде необходимо преодолеть энергетический барьер, соответствующий окислительному потенциалу $+1.05 \mathrm{~V}$ [18], затем окислительный потенциал реакции снижается. С целью оптимизации процесса преобразования мономера в высокомолекулярное соединение, окислительную полимеризации 2-(1-циклопент-2-ен-1-ил)анилина проводили варьируя времена проведения и количество вводимого окислителя (табл. 1 и 2). Концентрацию мономера при этом оставляли на постоянном уровне, изменяя концентрацию персульфата аммония от эквивалентного содержания по отношению к $M$ до избытка в 2.25 .

На основании табличных данных установлено, что оптимальное время проведения реакции составляет $36 \mathrm{~h}$, a предпочтительным мольным соотношением мономер: окислитель представляется $1.00: 1.75$, поскольку в этом случае достигается наилучший выход. При дальнейшем увеличении концентрации окислителя и време- ни процесса выход полимера снижается. По-видимому, наблюдаемое связано с тем, что при избытке окислителя протекает окисление аминных звеньев полимерной цепи.

\section{2. Извлечение растворимой фракции полимера и его растворимость}

Одна из важнейших характеристик получаемого полимера - его растворимость. Для выявления оптимального растворителя оценивали два параметра - извлечение (эффективность растворения) и растворимость. Под извлечением понимается количество растворимой части полимера от общей массы при промывании его растворителем; характеризует эффективность растворителя по отношению к полимеру. Растворимость - мера, характеризующая количество растворимого полимера в единице объема растворителя. В этой связи изучена растворимость образца $P$ в серии отличающихся по полярности типовых органических растворителей (табл. 3).

Согласно данным таблицы, лучший растворитель из представленных - наиболее полярный апротонный ДМФА.

Более высокая растворимость в органических растворителях гомополимера $P$ относительно ПАНИ можно объяснить присутствием циклоалкенильных заместителей в элементарных звеньях макромолекулы, в результате чего имеет место повышение гибкости цепи относительно жесткой структуры ПАНИ.

\section{3. Исследование электрофизических свойств производного полианилина}

Изучение температурных зависимостей электропроводности материала дает информацию о том, является ли транспорт заряда активационным процессом, либо в полимере присутствуют свободные носители и органи-

Таблица 2. Оптимизация реакции окислительной полимеризации $M$ по количеству вводимого окислителя при проведении процесса $36 \mathrm{~h}$

\begin{tabular}{c|c|c|c|c|c|c}
\hline $\begin{array}{c}\text { Соотношение } \\
\begin{array}{c}\text { мономер: окислитель, } \\
\text { то1 }\end{array}\end{array}$ & $1.00: 1.00$ & $1.00: 1.25$ & $1.00: 1.50$ & $1.00: 1.75$ & $1.00: 2.00$ & $1.00: 2.25$ \\
\hline Выход $P, \%$ & 30.4 & 42.1 & 50.0 & 51.6 & 49.4 & 49.3
\end{tabular}

Таблица 3. Извлечение и растворимость полимера $P$ в различных растворителях

\begin{tabular}{l|c|c}
\hline Растворитель & $\begin{array}{c}\text { Количество } \\
\text { растворимой части, } \%\end{array}$ \\
\hline Толуол & 0.7 & 24.0 \\
Хлороформ & 3.5 & 20.3 \\
Ацетонитрил & 5.5 & 20.4 \\
ДМФА & 22.2 & 37.6 \\
Этанол & 12.3 & 24.7 \\
Хлорбензол & 4.8 & 35.8
\end{tabular}




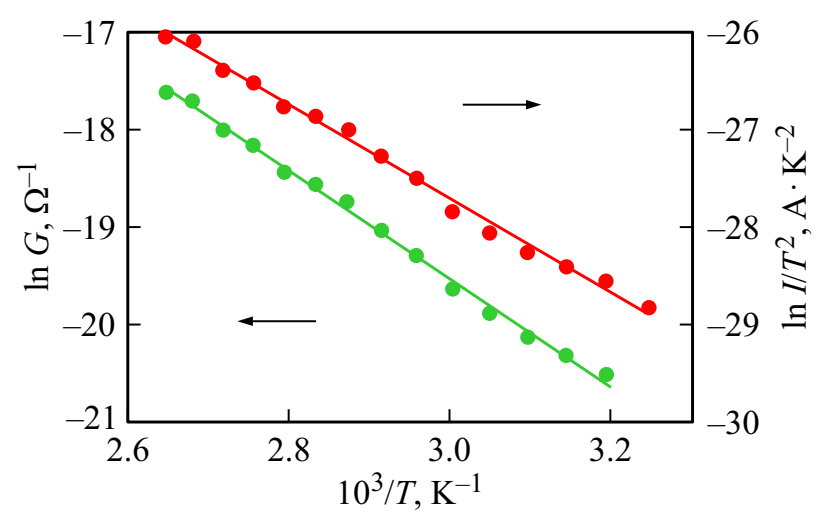

Рис. 2. Зависимость проводимости и логарифма величины $I / T^{2}$ от обратной температуры для пленок поли-2-(1-циклопент-2-ен-1-ил)анилина $(P)$.

ческая система полисопряжения способна реализовать металлическое состояние.

Так, нами измерены зависимости проводимости сформированных из синтезированного полимера пленок от температуры. Температурные измерения проводимости пленок $G$ в интервале $300-450 \mathrm{~K}$ показали экспоненциальный характер зависимости $G$ от обратной температуры $T$ :

$$
G=G_{0} \exp \left(-\frac{\Delta E}{2 k T}\right)
$$

В координатах $\ln G-1000 / T$ экспериментальные точки в пределах погрешности укладываются на прямую (рис. 2). Величину $\Delta E$ можно интерпретировать как интервал между ВЗМО и НСМО (аналог запрещенной зоны) в полупроводниковых полимерных пленках. Расчет по приведенной зависимости показывает, что этот интервал составляет величину $0.96 \mathrm{eV}$.

Чтобы понять, каким образом осуществляется транспорт заряда через границу металл-полимер, были перестроены температурные зависимости проводимости в координатах Шоттки (рис. 2) в соответствии с формулой

$$
J=A^{*} \times T^{2} \exp \left[\frac{-e\left(\varphi_{B}-\sqrt{e F / 4 \pi \varepsilon \varepsilon_{0}}\right)}{k T}\right],
$$

где $J$ - плотность тока, $A^{*}$ - постоянная Ричардсона, $e-$ заряд электрона, $\varphi_{B}-$ высота барьера, $F-$ напряженность электрического поля, $\varepsilon$ - диэлектрическая проницаемость образца, $\varepsilon_{0}$ - электрическая постоянная, $k$ - постоянная Больцмана, $T$ - температура.

График $I / T^{2}$ от обратной температуры в пределах погрешности измерений хорошо аппроксимируется прямой. Согласно формуле (1), тангенс угла наклона прямых участков пропорционален высоте барьера Шоттки $\varphi_{B}$.

Анализируя полученную зависимость, можно предположить, что основным механизмом переноса является термоэлектронная эмиссия Шоттки, которая определяет транспорт носителей заряда через границу металлической подложки и полимерной пленки в диапазоне температур 300-450 K. Это подтверждает вывод о том, что переход носителя заряда через границу металл-полимер осуществляется в результате надбарьерного переноса. Причем, высота барьера определяется разницей работы выхода металла и электронным сродством полимеpa [19]. Например, для пленочных образцов расчет из электрофизических измерений дает величину $0.41 \mathrm{eV}$. C учетом полевой добавки в формуле (2), которая составляет величину порядка $0.1 \mathrm{eV}$, высота барьера Шоттки - $0.51 \mathrm{eV}$. Вычитая из работы выхода $\mathrm{Al}-$ $4.26 \mathrm{eV}$ рассчитанное значение барьера Шоттки $0.51 \mathrm{eV}$, получаем величину электронного сродства полимера $3.75 \mathrm{eV}$, то есть имеем сопоставимую величину со значением, определенным из модели Шоттки. Таким образом, приведенные выше расчеты являются свидетельством, подтверждающим модель надбарьерного переноса на границе металл-полимер.

Пользуясь формулой (2), можно оценить величину тока, проходящего через исследуемый образец. Исходя из значения $A^{*}=120.4 \mathrm{AK}^{-2} \mathrm{~cm}^{-2}-$ термоэлектрическая постоянна в модели свободных электронов, площади контакта порядка $10^{-5} \mathrm{~cm}^{2}$, температуры $400 \mathrm{~K}$, высоты барьера Шоттки, величина тока через образец получается порядка 3-4 $\mathrm{A}$. Экспериментально измеренные значения тока составляли величину порядка $0.8 \mu \mathrm{A}$. Проведенные оценочные вычисления свидетельствуют в пользу модели Ричардсона-Шоттки о переносе носителей заряда через границу металл-полимер в результате надбарьерного переноса [20].

Ниже, на рис. 3, приведены выходные и передаточные характеристики полевых транзисторов. Увеличение токов в созданном полевом транзисторе наблюдается при отрицательном напряжении на затворе, что соответствует дырочному типу проводимости транспортного канала транзистора. Зависимости имеют нелинейный характер. На выходных характеристиках участки насыщения отсутствуют из-за наличия токов утечки.

Была проведена оценка подвижности носителей заряда из вольтамперной характеристики полевого транзистора, изготовленного на основе исследованного полимера. Подвижности носителей заряда активного слоя $\mu$ полевого транзистора оценивались с помощью формулы (3)

$$
I_{D S}=(W / L) \mu C\left(U_{G}-U_{\mathrm{th}}\right) U_{D S},
$$

где $W$ - ширина канала, $L$ - длина канала, $C$ емкость на квадрат площади подзатворного диэлектрика (для толщины $500 \mathrm{~nm}, C=0.7 \mathrm{nF} \cdot \mathrm{cm}^{-2}$ ), $U_{G}$ - напряжение на затворе, $U_{D S}$ - напряжение между стоком и истоком, $U_{\text {th }}$ - пороговое напряжение. Рассчитанное значение подвижности носителей: $2.0 \mathrm{~cm}^{2} \cdot \mathrm{V}^{-1} \cdot \mathrm{s}^{-1}$. Полученные значения сопоставимы с аналогичными данными, полученными в последнее время для пленок ПАНИ и их производных, используемых в органической электронике [21]. 

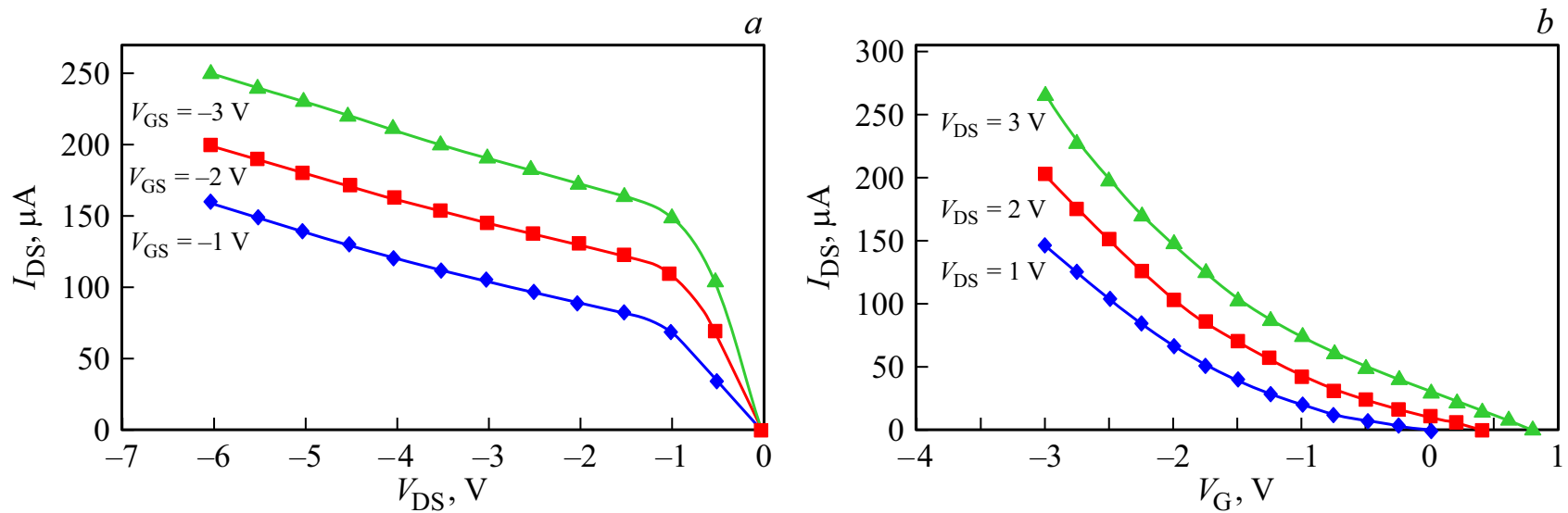

Рис. 3. Выходные $(a)$ и передаточные $(b)$ характеристики для полевых транзисторов на основе пленок поли-2-(1-циклопент-2-ен-1-ил)анилина $(P)$.

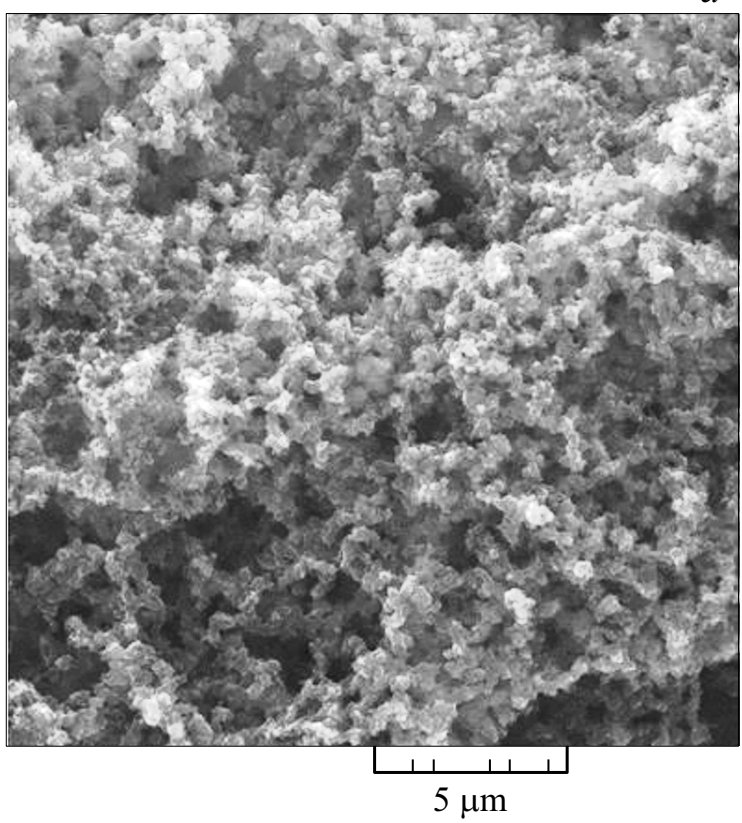

$b$

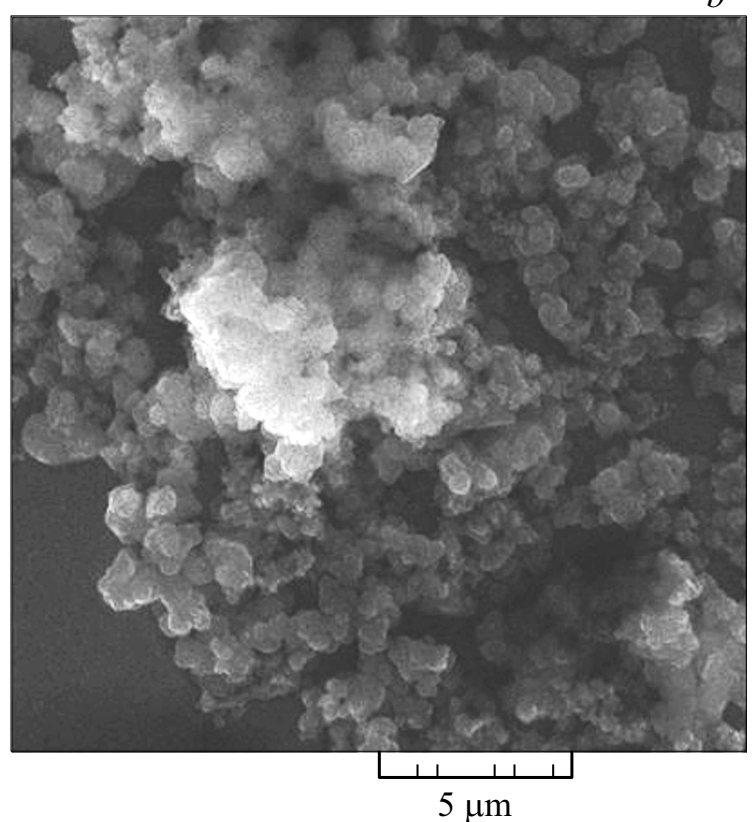

Рис. 4. РЭМ изображения (a) ПАНИ и $(b)$ поли-2-(1-циклопент-2-ен-1-ил)анилина $(P)$.

\section{4. Анализ морфологии поверхности}

Окислительная полимеризация анилина и его производных приводит к получению большого количества микро- и наноструктур разных размеров и форм [22]. Изменение синтетических условий оказывает кардинальное влияние на наномасштабированную морфологию полученного полимера.

Исследование микроструктуры наночастиц проводили с помощью высокоразрешающего растрового электронного микроскопа (РЭМ). Морфология функционализированного полианилина $P$ значительно отличается от структуры немодифицированного: на рис. 4 видно, что последний обладает волокнистой наноструктурой, в то время как РЭМ изображение полимера $P$ имеет морфологию, состоящую из взаимосвязанных глобулярных структур. Поскольку образцы получены в одинаковых условиях, выявленные отличия в морфологии связаны непосредственно с механизмом взаимодействия мономерных единиц. Следовательно, надмолекулярная структура полимера значительным образом зависит от природы заместителей в ароматическом кольце.

\section{5. Термогравиметрическое исследование поли-2-(1-циклопент-2-ен-1-ил)анилина}

Группа термических методов анализа позволяет определить процессы, происходящие в веществе, что в дальнейшем находит отражение в изменении его эксплуатационных характеристик. Исследование деструкции син- 


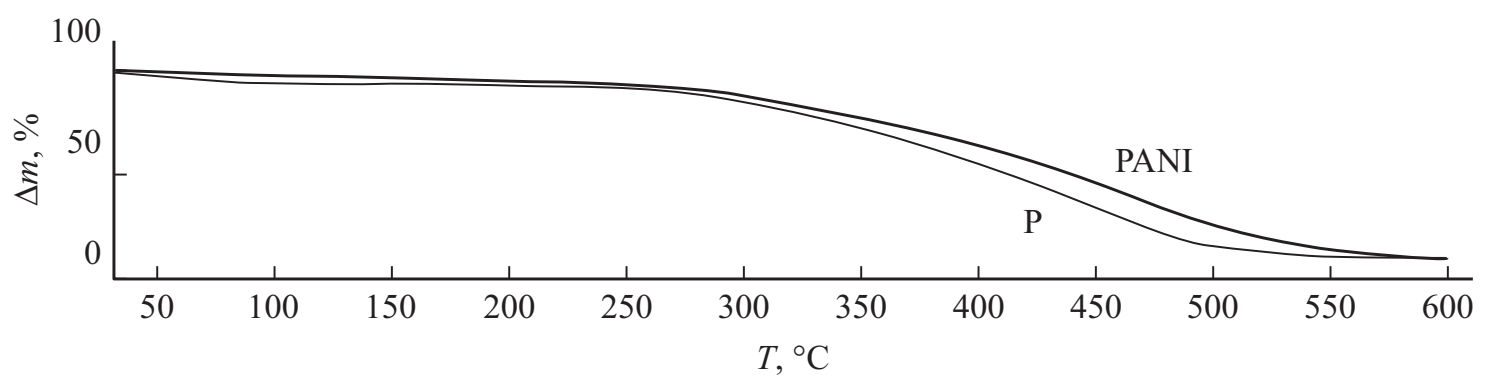

Рис. 5. Дериватограммы образцов ПАНИ и поли-2-(1-циклопент-2-ен-1-ил)анилина $(P)$.

Таблица 4. Параметры термостабильности ПАНИ и поли-2-(1-циклопент-2-ен-1-ил)анилина $(P)$

\begin{tabular}{|c|c|c|c|c|c|c|}
\hline Образец & $\begin{array}{l}T_{5}, \\
{ }^{\circ} \mathrm{C}\end{array}$ & $\begin{array}{c}\text { Интервал } \\
\text { разложения, }{ }^{\circ} \mathrm{C}\end{array}$ & $\begin{array}{c}\Delta m, \\
\%\end{array}$ & $\begin{array}{l}T_{m}, \\
{ }^{\circ} \mathrm{C}\end{array}$ & $\begin{array}{l}T_{\text {пл }}, \\
{ }^{\circ} \mathrm{C}\end{array}$ & $\begin{array}{c}m_{600}, \\
\%\end{array}$ \\
\hline ПАНИ & 193.7 & $111.1-570.8$ & 89.6 & 467.8 & 469.2 & 4.3 \\
\hline$P$ & 171.5 & $96.1-587.3$ & 94.3 & 468.7 & 469.1 & 6.4 \\
\hline
\end{tabular}

тезированного полимера необходимо как для прогнозирования поведения материалов на его основе в реальных условиях применения, так и для выяснения механизма разложения с целью повышения термической стойкости веществ.

В ходе термогравиметрического анализа определенные параметры термической устойчивости поли-2(1-циклопент-2-ен-1-ил)анилина $(P)$ сопоставлялись с исходным ПАНИ. Полученные термогравиметрические кривые и соответствующие им данные представлены на рис. 5 и сведены в табл. 4. Как видно, дериватограммы имеют однотипный вид, что свидетельствует о схожем механизме поведения полимеров при деструкции. Установлено, что температура начала разложения $T_{5}$, характеризующая изменение (снижение) массы образцов полимера на $5 \%$, для $P$ на $22^{\circ} \mathrm{C}$ сдвинута в более низкотемпературную область, относительно его не модифицированного аналога, что объясняется начинающейся деструкцией боковых циклоалкенильных заместителей. Основная потеря массы исследуемых образцов происходит в одну ступень (стадию) разложения в интервале температур $111.1-570.8^{\circ} \mathrm{C}$ и $96.1-587.3^{\circ} \mathrm{C}$, соответственно для самого ПАНИ и его модифицированного аналога. Наличие боковых ответвлений в последнем расширяет данный температурный интервал в обоих направлениях.

Наиболее интенсивное разложение полимера, связанное с расщеплением основной макромолекулярной цепи (сопровождается выделением газообразных продуктов) и конечной деструкцией полимера проходит в области температур $240-570^{\circ} \mathrm{C}$, о чем свидетельствуют характерные пики на последних кривых DTG с максимумами $T_{m} \sim 468^{\circ} \mathrm{C}$ в обоих случаях (табл. 4). До температуры $600^{\circ} \mathrm{C}$ происходит практически полное разложение полимера: коксовый остаток продукта составляет примерно 5\%.

\section{4. Выводы}

По результатам проделанной работы можно сделать следующие выводы:

1. На основе функционализированного мономерного анилина - 2-(1-циклопент-2-ен-1-ил)анилина впервые синтезирован и охарактеризован растворимый в типовых органических растворителях электронодонорный проводящий полимер. Установлено, что оптимальным мольным соотношением мономер : окислитель является $1.00: 1.75$ при времени проведения реакции $36 \mathrm{~h}$.

2. В результате исследования зависимости электропроводности от температуры определен интервал ВЗМО - НСМО для полученного высокомолекулярного соединения и предложена модель надбарьерного переноса на границе металл-полимер.

3. На основе вольтамперных характеристик полевых транзисторов, в которых в качестве транспортного слоя были использованы синтезированные полимеры, рассчитаны значения подвижностей носителей заряда.

4. Сравнительный анализ морфологии ПАНИ и его функционализированного аналога выявил различия в структурах полимеров: если для первого характерна волокнистая наноструктура, то введение циклоалкенильного заместителя в орто- положение анилина приводит к образованию полимера с глобулярной структурой.

5. Термогравиметрическое изучение полимеров показано, что параметры термической устойчивости поли2-(1-циклопент-2-ен-1-ил)анилина сопоставимы с исходным ПАНИ, что говорит об схожем термоустойчивом механизме поведения материалов при деструкции.

\section{Финансирование работы}

Работа выполнена по теме № AAAА-A19119020890014-7 госзадания.

\section{Конфликт интересов}

Авторы заявляют, что у них нет конфликта интересов. 


\section{Список литературы}

[1] J. Stejskal, R.G. Gilbert. Pure Appl. Chem. 74, 5, 857 (2002).

[2] Э.Р. Блайт, Д. Блур. Электрические свойства полимеров. Физматлит, М. (2008). 375 с.

[3] В.А. Мошников, Е.И. Теруков. Основы водородной энергетики. ЛЭТИ, СПб (2011). С. 288.

[4] И.Ю. Пинус, А.Б. Ярославцев, Е.Н. Насибуллин, В.Г. Сергеев, В.А. Кабанов. Журн. неорган. химии 51, 1035 (2006).

[5] D.C. Trivedi. Polyanilines. Handbook of Organic Conductive Molecules and Polymers. / Ed. H.S. Nalwa. Wiley, Chichester, (1997). V. 2. 505 p.

[6] T.J. Rivers, T.W. Hudson, C.E. Schmidt. Adv. Func. Mater. 12, 33 (2002).

[7] T.F. Otero, J.G. Martinez, J. Arias-Pardilla. Electrochim. Acta. 84, 112 (2012).

[8] B. Wessling. Synth. Met. 3, 143 (1998).

[9] S. Bhadra, D. Khastgir, N.K. Singha, J.H. Lee. Prog. Polym.Sci. 34, 783 (2009).

[10] E.M. Genies̀, A. Boyle, M. Lapkowski, C. Tsintavis. Synth. Met. 36, 139 (1990)

[11] Ю.Н. Биглова, Р.Б. Салихов, И.Б. Абдрахманов, Т.Р. Салихов, И.Н. Сафаргалин, А.Г. Мустафин. ФТТ 59, 1228 (2017).

[12] D.D. Borole, U.R. Kapadi, P.P. Mahulikar, D.G. Hundiwale. Mater. Lett. 58, 3816 (2004).

[13] D.D. Borole, U.R. Kapadi, P.P. Mahulikar, D.G. Hundiwale. Mater. Lett. 60, 2447 (2006).

[14] И.Л. Кнунянц. Химический энциклопедический словарь. Сов. энциклопедия, М. (1983). 792 с.

[15] Л. Титце. Препаративная органическая химия. Реакции и синтезы в практикуме органической химии и научноисследовательской лаборатории. Мир, М, (1999). 704 с.

[16] И.Б. Абдрахманов, А.Г. Мустафин, В.М. Шарафутдинов. Перегруппировка Кляйзена в ряду ароматических аминов. Гилем, Уфа. (2014). 168 с.

[17] T. Higuchi, K.A. Connors. Adv. Anal. Chem. Instrum. 4, 117 (1965).

[18] L.Y.O. Yang, C.Z. Chang, S.H. Liu, C.G. Wu, S.L. Yau. J. Amer. Chem. Soc. 129, 8067 (2007).

[19] R.B. Salikhov, A.A. Bunakov, A.N. Lachinov. Phys. Solid State. 49, 1, 185 (2007).

[20] R.B. Salikhov, A.N. Lachinov, R.G. Rakhmeyev. Mol. Cryst. Liq. Cryst. 467, 1, 85 (2007).

[21] Y.-C. Li, Y.-J. Lin, H.-J. Yeh, T.-C. Wen, L.-M. Huang, Y.-K. Chen, Y.-H. Wang. Appl. Phys. Lett. 92, 093508 (2008).

[22] H.D. Tran, J.M. D’Arcy, Y. Wang, P.J. Beltramo, V.A. Strong, R.B. Kaner. J. Mater. Chem. 21, 3534 (2011).

Редактор Т.Н. Василевская 